\title{
Towards a Security Governance Agenda in Post-Conflict Peacebuilding
}

\author{
Alan Bryden*
}

\begin{abstract}
The decision to create a United Nations Peacebuilding Commission demonstrates the international community's recognition of the need for further efforts to prevent the recurrence of conflict in fragile States. Indeed, there are still considerable gaps in the development of concepts, policies and practice that would facilitate post-conflict peacebuilding and make it more effective. One such gap lies in the security dimension of post-conflict peacebuilding. Applying a security governance approach to the range of security issues that must be addressed by both post-conflict societies and the international community provides a means to better understand the opportunities for more effective and coordinated international efforts to build up domestic capacity for the provision of security.
\end{abstract}

Keywords: Security governance, Security sector reform, Post-conflict peacebuilding

\section{Introduction ${ }^{2}$}

$\mathrm{T}$ he first Human Security Report ${ }^{3}$, somewhat counter-intuitively, demonstrates that armed conflicts, and the number of people killed in them, have declined significantly since the end of the Cold War. The report shows that a major increase in the number of peacebuilding activities - from conflict prevention to peacekeeping and post-conflict peacebuilding - has had a profound, positive effect on global security. While recognizing the contribution of the international community, in particular the United Nations (UN), in achieving these results, the report also points out that 40 per cent of post-conflict States fall back into political violence within five years. ${ }^{4}$ This statistic demonstrates that, looking beyond the considerable achievements to date, much still needs to be done in this field. It reinforces the importance of sustained, joined up and targeted efforts by international actors, in partnership with societies emerging from conflict, in order to reduce the likelihood of a return to conflict and to provide a framework for a secure and peaceful future through addressing the security needs of the state and its citizens in parallel with socio-economic aspects of reconstruction.

Post-conflict peacebuilding is characterised by a complex, multilayered architecture of actors and mechanisms interacting in related yet disconnected security and development fields which span all territorial levels of interaction from sub-state to state, regional and global levels. International organisations and transnational private actors play a key role. International regimes and conventions establish normative frameworks in areas such as human rights law (HRL) and international humanitarian law (IHL) as well as in discrete areas such as small arms and light weapons (SALW), mine action, and child soldiers. In many post-conflict states, armed non-state actors such as irregular paramilitary forces and remnants of armed rebel groups remain significant players on the substate level of security governance and therefore need to be engaged. Finally,

* Alan Bryden is Deputy Head of Research at the Geneva Centre for the Democratic Control of Armed Forces (DCAF).

2 This article is drawn from the findings of a recent DCAF publication on post-conflict peacebuilding: Bryden, Alan/Hänggi, Heiner (ed.) 2005: Security Governance in Post-Conflict Peacebuilding, Lit Verlag, Münster.

3 The Human Security Centre, University of British Columbia 2005: The Human Security Report 2005, Oxford University Press.

4 Ibidem, p. 154 highly politicised issues such as security sector reform (SSR) and transitional justice embody a normative governance dimension in that they presuppose the existence of political institutions capable of enforcing principles of good governance and democratic accountability.

Better understanding these linkages in conceptual and practical terms is essential in order to integrate efforts more systematically and foster synergies among stakeholders both at the strategic level and in the field. Analysing these issues from the perspective of security governance, ${ }^{5}$ which combines an onus on effective and efficient security provision with the need for good governance of the security sector, provides a means to better link disparate stakeholders and their activities. It also underlines the fundamental requirement, admittedly a highly challenging and long term endeavour, to nurture local ownership in peacebuilding programmes and develop genuine capacity among indigenous security actors as well as in the institutions that provide for their management and oversight.

On the conceptual level, a better understanding of the linkages between these issues is required. In policy terms, there is a need for consolidation of emerging good practice. Finally, different approaches and endeavours must be coherently integrated into post-conflict peacebuilding programmes. In order to clarify the security governance dimensions of post-conflict peacebuilding this article addresses three overarching themes which mirror the discourse on peacebuilding within the UN Security Council: Security Sector Reform and Governance; Disarmament, Demobilisation and Reintegration; and Rule of Law and Transitional Justice. ${ }^{6}$ It then assesses some of the cross-cutting issues that link them and the implications of this analysis for the broader goals of post-conflict peacebuilding.

\footnotetext{
5 For the concept of »security governance« see Hänggi, Heiner 2005: Approaching Peacebuilding from a Security Governance Perspective, in: Bryden/Hänggi 2005, pp. 3-19.

6 See, inter alia United Nations Security Council 2005: Statement by the President of the Security Council, S/PRST/2005/30 of 12 July 2005, Remarks to the Open Meeting of the Security Council on »Maintenance of International Peace and Security - The Role of the Security Council in Humanitarian Crises: Challenges, Lessons Learned, the Way Ahead «; United Nations Security Council 2005: Statement by Mr. Jean-Marie Guéhenno, Under Secretary-General for Peacekeeping Operations, S/PV.5225, of 12 July 2005; Permanent Mission of Greece to the United Nations 2005: Concept Paper for the July 12th Security Council Thematic Debate on $»$ Maintenance of International Peace and Security, The Role of the Security Council in Humanitarian Crises: Challenges, Lessons Learned, the Way Ahead«.
} 


\section{Security Sector Reform and Governance}

SSR is a relatively new concept that has received growing support among actors involved in such diverse fields as development assistance, security cooperation and democracy promotion. ${ }^{7}$ It is driven by the understanding that an unreformed security sector represents a decisive obstacle to the promotion of sustainable development, peace and security. SSR is therefore aimed at the efficient and effective provision of state and human security within a framework of democratic governance. Thus, SSR is intended to reduce security deficits (lack of security or even provision of insecurity) as well as democratic deficits (lack of oversight of the security sector). The SSR agenda favours a holistic approach in a double sense - firstly by integrating all those partial reforms such as defence, police, intelligence and judicial reform, which in the past were generally seen and conducted as separate efforts; and secondly, by linking measures aimed at increasing efficiency and effectiveness of security forces to overriding concerns of democratic governance. A key element of the SSR concept is that it goes beyond state-centric approaches, particularly important given that post-conflict contexts are characterised by weak or non-existent state structures. Effective SSR, therefore, addresses other influential post-conflict actors such as peacekeeping forces and transitional administrations, non-statutory civil society groups and armed non-state actors. In this regard, the governance dimension is fundamental to the SSR concept: supporting the effectiveness of security sector actors without reference to good governance and democratic oversight does not constitute SSR, even if conferring this nomenclature on such activities may provide a useful flag of convenience for some.

A major dilemma of security sector reconstruction ${ }^{8}-$ SSR in post-conflict settings - lies in the fact that it is externally induced, funded and driven, creating an inherent tension between local ownership and external assistance. In operational terms this presents a danger of imposing external reform models that do not reflect local realities and needs. Also, external actors may provide security and governance frameworks while ignoring the development of indigenous capacities to take up such duties in the longer run. Sierra Leone provides just such an example where, despite the dedicated and sustained commitment of the UK to a holistic SSR programme in that country, serious questions remain as to the sustainability of these reforms should this support be withdrawn. ${ }^{9}$ This example reflects a broader concern that the internationalisation and privatisation of the provision of post-conflict security greatly complicates opportunities for meaningful SSR. Western donors, multilateral organisations, non-governmental organisations (NGOs) and commercial companies involved in a wide range of peacebuilding activities have displayed a limited appreciation of local contexts, resulting in wasted resources,

7 Security sector reform is discussed in issue $3 / 2005$ of S+F.

8 For a detailed analysis of security sector reconstruction and its application in various regional and national contexts see: Bryden, Alan/Hänggi, Heiner (eds.) 2004: Reform and Reconstruction of the Security Sector, Lit Verlag, Münster, full text available at www.dcaf.ch.

9 The case of Sierra Leone is discussed in: Bryden, Alan/N'Diaye, Boubacar/Olonisakin, Funmi 2005: Security Sector Governance in West Africa: Turning Principles to Practice, DCAF Policy Paper No. 8, available at www.dcaf.ch. unfulfilled expectations and consequent disillusionment on the part of local actors. In the case of private security companies (PSCs), highly involved in the security sector reconstruction of a number of states (notably, military, police and intelligence service reform), the absence of effective regulatory frameworks means that inappropriate approaches and conduct are rarely corrected or PSCs held to account. ${ }^{10}$ This leads to accountability deficits that fuel grievances among locals and undermine the legitimacy of external interventions. Empowering non-statutory civil society actors such as the media, NGOs, research institutions and community groups can enhance a valuable monitoring role, provide the state institutions responsible for the management and oversight of the security apparatus with alternative expertise, and at the same time create a counterweight to the deficits described above. It is also an effective means of moving away from donor-driven SSR approaches. However, building the right kinds of local capacity and avoiding the misguided support of suncivil society< can be problematic.

\section{Disarmament, Demobilisation and Reintegration}

DDR is a core element of post-conflict peacebuilding which, in its broader sense, incorporates both measures to deal with former combatants and physical remnants of war such as SALW and landmines. Failure to reintegrate former combatants can be directly linked to increased criminality and a return to violence. Former child soldiers represent an important subset of this category whose particular needs are often ignored in DDR programmes. In a different way, landmines and SALW are material legacies of war that heighten insecurity and undermine reconstruction and development efforts. If qualitatively different, they offer related challenges to post-conflict peacebuilding given that both have in common the need to address their socio-economic impact rather than the numbers of weapons per se. Moreover, apart from the disarmament dimension of these issues, addressing the threat posed by SALW and landmines offers potentially significant confidence-building benefits that can be accrued at national and community levels.

However, although the practical steps involved in DDR-related processes tend to be clear enough, the policy objectives behind these activities can be rather more obscure and consequently disjointed. Paradoxically, the reintegration element is the most challenging and least funded element of DDR. It is difficult to do because it is cross-disciplinary, linking the more immediate requirements of disarmament and demobilisation to the long term imperatives of economic and social welfare. Mine action and SALW programmes may suffer from similar problems if they focus on supply-side measures that miss the underlying governance deficits that are at the heart of these problems. In both cases, a narrow focus on specific »tasks « vitiates the wider requirement for developing transfer strategies to legitimate and effective national actors. Inter-

10 For a comprehensive analysis of this issue see: Caparini, Marina/Schreier, Fred 2005: Privatising Security: Law, Practice and Governance of Private Military and Security Companies, DCAF Occasional Paper No. 6. 
national responses are hampered by inadequate coordination and cooperation between stakeholders. These factors, which are exacerbated by short term and slowly disbursed funding, work against coherent, programmatic approaches that could build bridges between related peacebuilding endeavours.

The under-analysed linkages between SSR and DDR represent a specific area where developing synergies between these mutually-reinforcing activities could accrue significant wider advantages. ${ }^{11}$ Benefits would include cost savings, increased opportunities for the participants, and enhanced effectiveness of armed and security forces. DDR influences the conditions for SSR by setting initial force sizes and selecting candidates for demobilisation as well as through affecting the overall security situation with respect to crime and the likelihood of a return to conflict. Given the potential clashes of competing interests between military and civilian decision makers, the institutions of security governance offer a means to navigate through sensitive issues within a framework of democratic decision-making.

\section{Rule of Law and Transitional Justice}

Restoring the rule of law and guaranteeing the protection of individuals and communities is a vital pre-condition for post-conflict peacebuilding. The development of a new or reconstructed security sector must be underpinned by legitimacy and accountability in order to gain the trust of the citizens it is intended to protect. Support by the international community for transitional justice programmes requires a difficult balancing act between the imperatives of peace, justice and security. The various mechanisms of transitional justice - prosecutions, truth commissions, reparations, institutional reform and reconciliation - provide a means of addressing root causes of conflict through dealing with the past rather than allowing the residue of painful events to fester. Public attention, focused through trials, truth commissions and public hearings offer a mechanism to catalyse debate and give a voice to the public, therefore enhancing the prospects of dealing constructively with grievances.

Establishing and protecting the rule of law in post-conflict peacebuilding can only be achieved through fostering effective national executive, legislative and judicial institutions. It requires comprehensive strategies that promote accountability, justice as well as the applicability of relevant normative and legal frameworks, in particular IHL and HRL. International transitional administrations - as in Kosovo and Haiti ${ }^{12}$ have been created by the international community to provide such governance frameworks where domestic structures have been destroyed or neglected and national actors are unable to provide for the rule of law. These bodies have a dual responsibility to apply the rule of law in their own conduct and to their administrative functions in order to provide a suitable environment for an eventual handover of ownership to local actors.

11 See: Brzoska, Michael 2005: Embedding DDR Programmes in Security Sector Reconstruction', in: Bryden, /Hänggi 2005, pp. 95-113.

12 See contributions by Søren Jessen-Petersen and Rama Mani in this issue.
Respect for the rule of law is directly linked to opportunities for SSR. Trust in reconstituted security actors, and the post-conflict governance framework more broadly, will not be forthcoming and stability will therefore not be achieved if force is used indiscriminately, minorities left unprotected, individuals detained without due process or security forces are free to act with impunity. At the international level, the normative and legal framework has evolved in recent years and been reinforced through the entry into force of the Statute of the International Criminal Court (ICC). ${ }^{13}$ A further important development was the submission to the Security Council by the UN Secretary General in October 2004 of a report setting out for the first time the UN's approach to transitional justice issues. ${ }^{14}$ In operational terms, the combination of targeted prosecutions, a sound vetting programme and a robust truth commission can greatly facilitate the reform of security agencies. To give one example, SSR in post-Apartheid South Africa was significantly enhanced by the work of the Truth and Reconciliation Commission and the subsequent departure from office of senior officers whose crimes had been revealed.

\section{Cross-Cutting Issues}

Beyond the general conditions that apply to all post-conflict contexts, a number of specific security, political and socio-economic framing conditions are particularly important in shaping the specific opportunities, constraints and entry points for post-conflict peacebuilding. These conditions tend to be deeply ingrained and while they must be taken into account in formulating peacebuilding strategies, they can only be influenced to a certain extent by external actors.

- From a security perspective, the duration of a conflict, level of violence, factionalism and ethnic or religious dimensions all shape opportunities for post-conflict peacebuilding. The cross-border security dimensions of conflict are particularly significant with soldiers and arms flowing to and from different conflict zones.

- Political development prior to the conflict and how that was reflected in the pre-conflict security sector will shape possibilities and expectations for the post-conflict political dispensation. States that have historically provided neither security nor democratic governance, but instead have been characterised by corruption, clientism and repression, will be subject to a residual lack of trust from their citizens, who may seek their security elsewhere such as through support for non-state armed actors. In such cases, civil society will have been repressed and is unlikely to be able to provide an effective monitoring role.

- Finally, the available social and economic capital is influential in shaping the potential for post-conflict peacebuilding. This is a particularly important rationale for investing in DDR programmes where the absence of economic opportunities

13 The Statute entered into force on 1 July 2002. As of 28 October 2005 there are 100 full States Parties.

14 United Nations Security Council 2004: Report of the Secretary General, The rule of law and transitional justice in conflict and post conflict societies, S/2004/616, of 3 August 2004 . 
encourages criminality and creates violence entrepreneurs who have little option but to fall back on the skills learned as combatants.

As discussed above, running through the grain of post-conflict peacebuilding is the sensitive truth that, by its very nature, it represents an external intervention in very specific, regional, national and local contexts. The UN with its non-partisan mandate is best placed to be accepted in this regard where individual states may carry heavy historical or cultural baggage. On a practical level, external involvement requires coordination between stakeholders with different objectives and approaches as well as cooperation to ensure that different mechanisms and activities are logically sequenced and genuinely reflect the needs of conflict affected societies. Directly linked to this is the challenge of building capacity and infusing a sense of ownership among national and local actors. Military personnel have often been at the forefront of the international community's SSR programming. However, military skills sets, while appropriate to certain activities, do not necessarily lend themselves to developing governance frameworks or building capacity in local actors. It should be self-evident that peace »building « is a long term endeavour that requires coordinated policy setting at the strategic level, the rapid provision of sustained and targeted resources, and a multidisciplinary approach based on an appropriate mix of expertise. Notwithstanding the serious difficulties of operating in challenging post-conflict environments, these are exactly the areas where the international community has been found wanting.

Emphasis on »local ownership« is ubiquitous in peacebuilding policy documents. Indeed, establishing sustainable national authorities and supporting domestic constituencies is a precondition for moving from immediate post-conflict to longer term development priorities. In practice, this has not been conducted well. On the one hand, openings are particularly limited in the wake of conflict with weak or illegitimate governance institutions, a lack of political space and security actors that have been skewed to regime interests rather than those of the State and its citizens. On the other, local ownership should not be confused with decisions taken by national actors from above that favour those in power rather than their citizens. Such approaches fail a basic test of security sector governance. It is widely recognized that civil society has a key role in post-conflict peacebuilding through promoting dialogue and reconciliation as well as holding national and international actors accountable. The media can play a particularly important role in raising awareness, monitoring government decisions and applying pressure. But donor support for such organisations, if not carefully targeted, runs the risk of elevating a civil society »elite « that meets donor requirements before the needs of their own constituencies. Civil society actors are also particularly vulnerable to changing donor priorities and funding levels. Moreover, building such capacity should not be seen as an alternative to dealing with broader issues of participation and legitimacy stemming from the thorny framing conditions that provided the backdrop to the previous conflict.

Sequencing of post-conflict peacebuilding activities in an »ideal« model would interweave national level policy devel- opment, constitutional and legal reform within a framework of local capacity building. In the inevitable absence of such ideal situations the integration and sequencing of related peacebuilding activities is required. For example, decisions on demobilisation of former combatants will have a significant impact on the parameters for security sector reconstruction so the composition and numbers of the different post-conflict security forces would be best dealt with at the outset of DDR activities rather than later. Clearing schools of landmines is only meaningful if teachers have been trained and are ready to take up their duties. A key issue of sequencing concerns the question of when to hand over responsibility to local actors. There are no fixed answers to this question but the tendency to date has been to hand over responsibility too soon as part of a politically driven exit strategy rather than a planned transfer based on a clear assessment of the governance capacities of the state in question by the international community.

A final cross-cutting issue lies in the potential offered by SSR in bridging the different activities that comprise the peacebuilding agenda. Although this is an emerging and therefore contested proposition, requiring significant further research and analysis, the holistic nature of the SSR concept spans a wide range of activities from political dialogue, policy and legal advice to training programmes, technical and financial assistance. Although comprehensive integration of these mechanisms and the wide range of actors with a stake in them may be unrealistic, there are clear opportunities for cross-fertilisation of expertise and the development of synergies: a security governance approach would inform decision making on questions such as the use of former soldiers in policing roles; expertise drawn from the field of transitional justice, notably vetting and institutional reform, could also make a much greater contribution to SSR; while a security governance perspective would also call for greater emphasis on addressing armed non-state actors in DDR efforts as well as in their use of SALW and landmines. In sum, security governance provides a frame of reference for all these concerns, including SSR, DDR and rule of law issues, which merits to be explored further.

\section{Conclusion}

The achievements of the international community in assisting States emerging from conflict are significant. But the consequences of States falling back into conflict are far more stark and immediate than the slow, difficult and long-term work of reconstructing the State and its capacity to provide security for its citizens within a framework of democratic governance. The array of actors and institutions - internal and external at state, sub-state and international levels - involved in post-conflict peacebuilding is inherently complex. Only through better understanding the linkages between them in conceptual and practical terms can potential synergies be exploited and the work of different stakeholders achieve their full potential.

The discourse on post-conflict peacebuilding within the UN Security Council, built around a triangle of SSR, DDR, and rule of law and transitional justice demonstrates the international community's recognition of the need for a holistic approach to this challenge. The decision to create a UN Peacebuilding 
Commission ${ }^{15}$ with a Peacebuilding Support Office and Peacebuilding Fund offers a potentially valuable mechanism to integrate different actors and approaches. The central challenge for this new body and indeed for the States that endorsed its creation will be to move from a recognition of the complexity of the challenge to effecting change in practice. This will require an acceptance of new ways of doing business that overcome particularistic interests and resist the pull of bureaucratic inertia. Political will is therefore the most important commodity in developing the role of the Peacebuilding Commission in a meaningful way.

15 United Nations General Assembly 2005: Final document of the High-level Plenary Meeting of the General Assembly, A/60/L.1, of 15 September 2005. See also the contribution by Ulrich Schneckener and Silke Weinlich in this issue.
There is a clear need to better link, sequence and optimise the diverse component parts of post-conflict peacebuilding. This article has argued that a security governance perspective - combining emphasis on the effective and efficient provision of security with the corresponding need for good governance of the security sector - provides a useful framework to better link these different stakeholders in the security dimensions of post-conflict peacebuilding. Much can be learned across different issue areas in terms of good (and bad) practice which can be used to inform future interventions. But the value of improved coordination and cooperation must be measured on the ground where gaps between policy and practice are most acutely felt.

\title{
Das Treuhandsystem der Vereinten Nationen als Mittel zum Peacebuilding?
}

\author{
Patrick Sutter*
}

\begin{abstract}
With the end of the Cold War a more pronounced view on states' domestic responsibilities emerged, as states are today understood to be internationally liable for their domestic conducts. In parallel the humanitarian principle to safeguard populations at risk, among others, accords the international community a right to intervene into states' domestic affairs. This article argues that the right of self determination paired with the right of intervention legalizes international nation- and peacebuilding efforts under the terms of the UN charter's long-forgotten provisions on trusteeships. It argues that these provisions allow a country's inhabitants or its eventual legitimate occupying power to transfer states to trustee status and thus UN guardianship. Trusteeship law could so serve as the legal basis for effective UN peacebuilding efforts.
\end{abstract}

Keywords: Vereinte Nationen, Treuhandsystem, Peacebuilding, VN-Charta

\section{Einleitung}

$\mathrm{S}$ eit dem Ende der relativ stabilen Ordnung des Kalten Krieges sieht sich die Staatengemeinschaft immer öfter veranlasst, mittels Interventionen eskalierende oder bereits vollständig eskalierte Konflikte zu beenden. Dies hat nicht zuletzt damit zu tun, dass sich die Staatengemeinschaft selbst Verpflichtungen auferlegt hat, die sie, will sie glaubwürdig bleiben, letztendlich auch zu erfüllen hat. Im Vordergrund stehen der Schutz der Zivilbevölkerung ${ }^{1}$ und das Verbot gewisser Waffenarten ${ }^{2}$ - also zwei der drei Grundpfeiler des klas-

\footnotetext{
* Patrick Sutter, lic, iur. HSG, ist in einer Anwaltskanzlei in Schwyz (Schweiz) tätig und hat kürzlich an der Universität St. Gallen seine rechtswissenschaftliche Dissertation zum Thema »Wissenschaft und Ethik in der Rechtsetzung « eingereicht. Er ist Milizoffizier in der Schweizer Armee und dient dort als Rechtsberater in der Sektion Kriegsvölkerrecht.

1 In diesen Fällen ist von »humanitären Interventionen« die Rede, so z.B. im Kosovo.

2 Es geht dabei v.a. um ABC-Waffen. Die (nicht nur militärische) Intervention im Irak war ursprünglich damit begründet.
}

sischen humanitären Völkerrechts. Es handelt sich bei diesen Interventionspflichten insofern gleichzeitig um Interventionsrechte, als die von der Intervention betroffenen Staaten keine verbotene Einmischung in interne Angelegenheiten geltend machen können. Ob ein solches Interventionsrecht besteht, entscheidet im System der kollektiven Sicherheit allein der Sicherheitsrat (SR) der Vereinten Nationen (VN). ${ }^{3}$ Alle nachfolgenden Ausführungen stehen deshalb unter dem Vorbehalt, dass die Intervention selbst völkerrechtskonform ist. ${ }^{4}$

\footnotetext{
3 Siehe etwa Donner, Michael 1995: Die Begrenzung bewaffneter Konflikte durch das moderne jus ad bellum, in: Archiv für Völkerrecht 33, 168ff.

4 »If this is not the case, as the two most recent cases of Kosovo and Iraq demonstrate, then we immediately run into severe problems of legitimacy and credibility of the UN system. This is why attempts to dump postconflict situations requiring reconstruction in the lap of the UN following unilateral or multilateral interventions not sanctioned by the SC should be strongly resisted. The SC and the UN's collective security mechanism should not be allowed to become tools in the hands of intervening powers who have done so without UNSC authorization, as happened in Kosovo and in Iraq" (Ayoob, Mohammed 2005: Post-Conflict Reconstruction, 1, unter: http://www.un-globalsecurity.org/pdf/Ayoob_paper_postconflict.pdf). Vergleiche auch A/Res/60/1, Ziff. 77.
} 